\title{
Should Bacteriophages Be Classified as Parasites or Predators?
}

\author{
GRZEGORZ WĘGRZYN \\ Department of Molecular Biology, Faculty of Biology, University of Gdańsk, Gdańsk, Poland \\ Submitted 28 November 2021, accepted 8 January 2022, published online 23 February 2022
}

\begin{abstract}
Bacteriophages are viruses infecting bacteria and propagating in bacterial cells. They were discovered over 100 years ago, and for decades they played crucial roles as models in genetics and molecular biology and as tools in genetic engineering and biotechnology. Now we also recognize their huge role in natural environment and their importance in human health and disease. Despite our understanding of bacteriophage mechanisms of development, these viruses are described as parasites or predators in the literature. From the biological point of view, there are fundamental differences between parasites and predators. Therefore, in this article, I asked whether bacteriophages should be classified as former or latter biological entities. Analysis of the literature and biological definitions led me to conclude that bacteriophages are parasites rather than predators and should be classified and described as such. If even more precise ecological classification is needed, bacteriophages can perhaps be included in the group of parasitoids. It might be the most appropriate formal classification of these viruses, especially if strictly virulent phages are considered, contrary to phages which lysogenize host cells and those which develop according to the permanent infection mode (or chronic cycle, like filamentous phages) revealing features of classical parasites.
\end{abstract}

Ke yw ords: bacteriophages, parasitism, predation, parasitoids

\section{Introduction}

Bacteriophages (or shortly, phages) - viruses infecting bacterial cells - have been known for over 100 years, and currently they are recognized as the most abundant biological entities on Earth (Salmond and Fineran 2015; Batinovic et al. 2019). Their biological significance in the natural environment is irrefutable (Correa et al. 2021), and examples of their use in medicine (Zalewska-Piątek and Piątek 2021) and biotechnology (Jaroszewicz et al. 2021) are very numerous.

Examples of tremendous roles of bacteriophages in the control of microbial communities in natural habitats include their action on water and soil bacteria to keep ecological equilibrium (Srinivasiah et al. 2008), their ability to mediate lateral transfer of bacterial genetic material, to modify bacterial cell metabolism, and - due to host cell lysis - to reallocate biochemical compounds originally present inside bacterial cells, thus contributing significantly to the circulation of matter in ecosystems (Naureen et al. 2020). They even participate in multi-organismal interactions in specific microbial trophic networks (Turnau et al. 2021). Properties of bacteriophages that make them able to affect bacterial communities have been employed to control and monitor wastewaters (Barrios et al. 2021; Liu et al. 2021).

Medical use of bacteriophages is focused on phage therapy, i.e., the use of these viruses to combat bacterial infections (Kortright et al. 2019). This approach receives more and more attention due to the appearance of numerous bacterial strains resistant to most or even all antibiotics used in clinical practice (Górski et al. 2020; Bhargava et al. 2021; Fathima and Archer 2021; Iszatt et al. 2021). Apart from the direct use of phages infecting pathogenic bacteria to patients, it is also essential to consider their application to control singleor mixed-species biofilms in therapy and protection of medical devices or food (Mgomi et al. 2021; Tian et al. 2021; Topka-Bielecka et al. 2021). Importantly, bacteriophages efficiently modulate the human microbiome, which has considerable effects on the physiology of the whole human organism (Pessione 2020; Duan et al. 2021; Hsu et al. 2021; Zhang et al. 2021). On the other hand, some bacteriophages encode toxins and other virulence

\footnotetext{
* Corresponding author: G. Węgrzyn, Department of Molecular Biology, Faculty of Biology, University of Gdańsk, Gdańsk, Poland; e-mail: grzegorz.wegrzyn@ug.edu.pl

(c) 2022 Grzegorz Węgrzyn

This work is licensed under the Creative Commons Attribution-NonCommercial-NoDerivatives 4.0 License (https://creativecommons. org/licenses/by-nc-nd/4.0/).
} 
factors, which if produced by bacterial cells after prophage induction, can cause severe human diseases (Casas and Maloy 2011; Łoś et al. 2011; Boyd 2012). Moreover, phages were also suggested as human pathogens (Tetz et al. 2017; Tetz and Tetz 2018). Therefore, interactions of bacteriophages with human and animal organisms must be carefully analyzed when considering the clinical use of these viruses (Podlacha et al. 2021).

There are numerous applications of bacteriophages or their genetic elements in genetic engineering and biotechnology. Bacteriophages can be used as cloning vectors, and regulatory elements of phage genomes serve as modules in sophisticated expression vectors (Harada et al. 2018). Phage display, based on exposing of foreign peptides on surfaces of bacteriophage virions, plays a significant role in the development of novel and very specific antibodies or antibody-like peptides, as well as in discovering new peptides with various functions useful is many fields of biotechnology and nanotechnology (Jaroszewicz et al. 2021). On the other hand, bacteriophages can be dangerous for the biotechnological processes when infecting bacteria used for large-scale synthesis of various bio-products in bioreactors (Łoś et al. 2004).

In the light of over 100 years of studies on these viruses, one scientific aspect appears surprising. Namely, in the literature, bacteriophages are presented either as parasites or predators. This ambiguity in the classification of phages is even more unexpected as they are described mostly in biological literature while biological definitions of parasitism and predation appear clear and straightforward. Therefore, I aimed to analyze this ambiguity and propose an unambiguous biological and ecological classification of bacteriophages.

\section{Calling bacteriophages parasites and predators}

When searching the PubMed database (https:// pubmed.ncbi.nlm.nih.gov), on January 2, 2022, the combination of terms "bacteriophage" and "parasite" gave 814 records, while the combination of terms "bacteriophage" and "predator" gave 345 records. When looking at various publications, bacteriophages are defined by researchers as either parasites or predators. The examples of the former classification are as follows: "Bacteriophages, the viral parasites of bacteria" (Betts et al. 2016), "host bacterium (...) and its viral parasite bacteriophage" (Gorter et al. 2015), "Phages are obligate intracellular parasites" (Orzechowska and Mohammed 2019). The examples of the latter classification are as follows: "Using phage-bacterial model systems, dynamics of the coexistence of predators and preys have been the subject of theoretical and experimental studies" (Lourenço et al. 2020), "As natural predators of bac- teria, phages can" (Hsu et al. 2021), "Bacteriophage ICP1: a persistent predator" (Boyd et al. 2021). Indeed, hundreds of other examples indicate bacteriophages as parasites or predators (see PubMed database https:// pubmed.ncbi.nlm.nih.gov for more examples).

\section{Biological definitions of parasites and predators}

When asking whether phages are parasites or predators, first, it is necessary to provide definitions of these terms. According to Dictionary.com (https:// www.dictionary.com), a parasite is "an organism that lives on or in an organism of another species, known as the host, from the body of which it obtains nutriment" (https://www.dictionary.com/browse/parasite), while a predator is "any organism that exists by preying upon other organisms" (https://www.dictionary.com/ browse/predator). The Merriam-Webster dictionary (https://www.merriam-webster.com) provides the following definition of a parasite: "an animal or plant that lives in or on another animal or plant and gets food or protection from it" (https://www.merriam-webster. $\mathrm{com} /$ dictionary/parasite), and the following definition of a predator "an animal that lives by killing and eating other animals: an animal that preys on other animals" (https://www.merriam-webster.com/dictionary/predator). As evident, various sources' definitions are similar, though they differ slightly in wording.

When considering a more specialistic source of definitions of parasitism and predation, one can use those provided by the New England Complex Systems Institute (Cambridge, MA, USA) (https://necsi.edu). According to this institute: "A parasitic relationship is one in which one organism, the parasite, lives off another organism, the host, harming it and possibly causing death. The parasite lives on or in the body of the host" (https://necsi.edu/parasitic-relationships); and "A predator is an organism that eats another organism. The prey is the organism which the predator eats" (https://necsi. edu/predator-prey-relationships). Finally, precise biological and ecological definitions are provided by Nature Education (Cambridge, MA, USA). On their web pages, the following definitions of parasitism and predation are found: "In parasitism, an individual organism, the parasite, consumes nutrients from another organism, its host, resulting in a decrease in fitness to the host" and "In predation, one organism kills and consumes another. Predation provides energy to prolong the life and promote the reproduction of the organism that does the killing, the predator, to the detriment of the organism being consumed, the prey", respectively (Stevens 2010). Although classical definitions of parasites and predators concern animals, it is evident that some plants can also be clearly included in one of these groups. Dodder 
(genus Cuscuta) (Noureen et al. 2019) and Venus flytrap (genus Dionaea) (Hedrich and Neher 2018) are examples of parasite and predatory plants, respectively.

Considering all the definitions provided above, to make a general statement, one may indicate that a parasite exploits its host to get nutriment and propagate either inside or on this organism when it is still living. On the other hand, a predator kills its prey and uses the death entity to get nutriment. Hence, one should note that there are drastic differences between biological/ ecological definitions of parasites and predators. The most important one is that a parasite exists in or on a living host, whereas a predator kills its prey and uses the resources of a dead creature. Sometimes, a predator can start to consume fragments of the prey even if it is not yet killed, but this event of consumption of a living prey is always short and strictly connected to the killing process. In other words, by definition, a predator does not feed on a still-living organism but kills it before or in the relatively short process of consumption.

\section{Lifestyles of bacteriophages}

Knowing the definitions of parasites and predators, let us analyze lifestyles of bacteriophages. There are generally three major developmental schemes of bac- teriophages, lytic cycle, lysogenic cycle, and permanent infection (chronic cycle), as summarized and depicted recently (Grabowski et al. 2021). See also Fig. 1 for a simple scheme. These developmental possibilities are presented briefly below, while for more details, a reader is referred to a recent book on bacteriophage biology (Harper et al. 2021).

In the lytic cycle, a bacteriophage infects a bacterial host by injecting its genome (either DNA or RNA) into the cell, followed by the phage genome replication and expression of its genes, leading to the formation of progeny phages. All these processes occur inside a living cell, and in fact, there are no lytic bacteriophages able to propagate in dead cells or even in non-growing cells. This is because phages use resources, both chemical compounds (including functional molecules, like enzymes and tRNAs, higher-order functional structures, like ribosomes, and low-molecular-mass compounds, likes nucleotides, amino acids, and ions) and energy (in the form of ATP and GTP), from a metabolically active host. Suppose the metabolism of a bacteriophage-infected bacterial cell is halted. In that case, some phages may enter a specific stage called 'pseudolysogeny', during which phage development is stopped, and its genome neither replicates nor is degraded inside the host cell, and no insertion into the host DNA is observed (Łoś and Węgrzyn 2012). A bacteriophage can
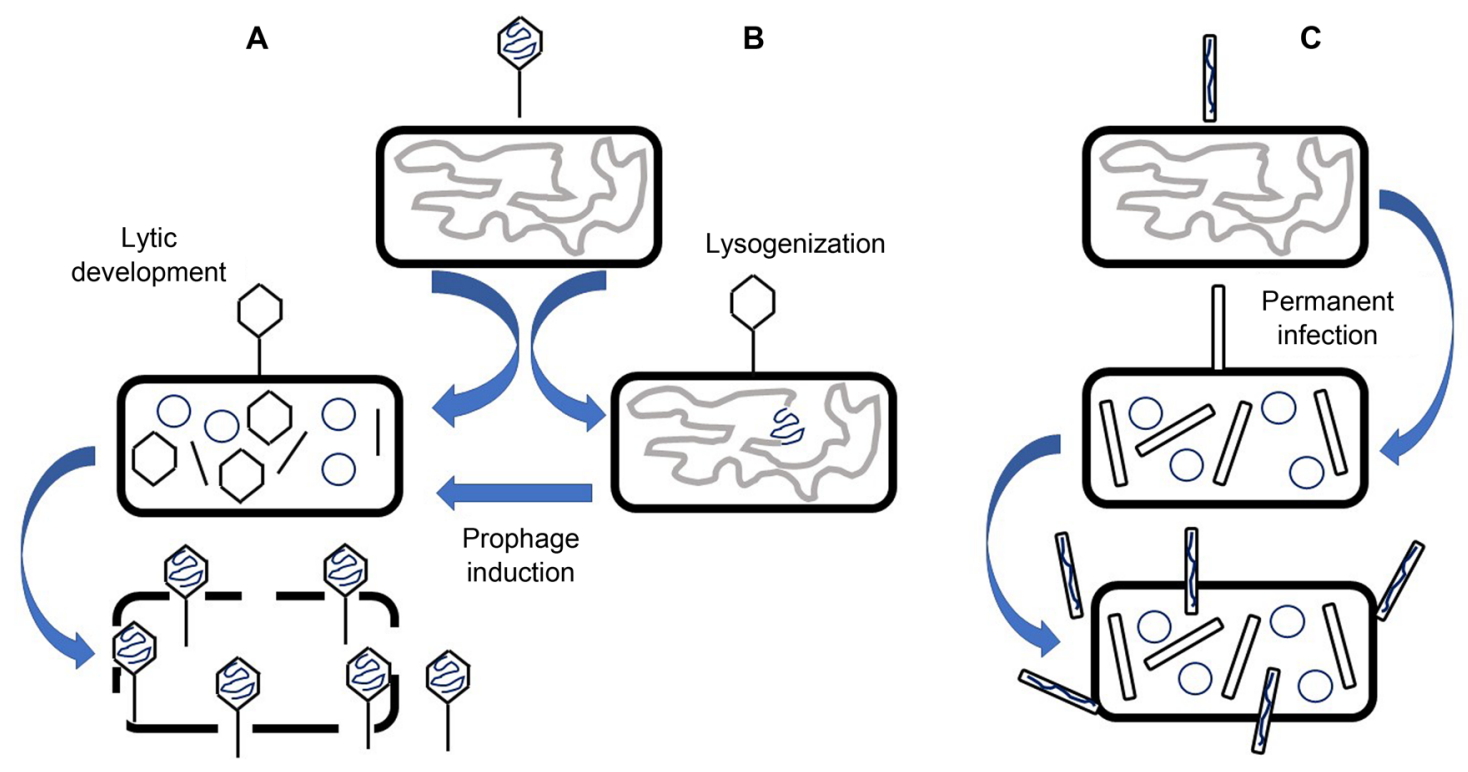

Fig. 1. Three developmental pathways of bacteriophages: lytic development (or lytic cycle) (panel A), lysogenization (or lysogenic cycle) (panel B), and permanent infection (or chronic cycle) (panel C). Phage virion (exemplified by a caudate phage in panels A and B, and a filamentous phage in panel C) adsorbs on the host cell and introduces its genome into this cell while the protein capsid remains outside the host. During the lytic development (A), the phage genome replicates intensively, and due to the expression of phage genes, structural proteins, forming capsids, are produced. After assembling progeny virions, the host cell is lysed due to the action of phage-encoded lytic proteins, and newly formed bacteriophages are liberated to the environment. During the lysogenic cycle (B), the phage genome integrates into the host chromosome by the site-specific recombination mechanism, forming a prophage, and it is passively replicated together with the bacterial nucleoid. In some cases, the phage genome can replicate as an extrachromosomal genetic element in the form of a plasmid. Under stress conditions, prophage is induced, phage DNA is excised from the host chromosome, and the development switches to the lytic mode. During the permanent infection $(\mathrm{C})$, the development proceeds similarly to that during the lytic cycle; however, the host cell is not lysed when progeny phages leave the bacterium; thus, production of newly formed bacteriophages and their release into the environment proceed continuously. 
restart its development only after re-establishing the cellular metabolism. The lytic development ends with host cell lysis and liberation of progeny phages. However, although the lysis means the death of the bacterial cells, one should note that bacteriophages no longer use the host resources after this event.

During the lysogenic cycle, the dependence of a bacteriophage on its living host is even more pronounced. In this case, after injection of the phage genome into the host cell, bacteriophage DNA is integrated into the bacterial chromosome, and then it is passively replicated as a part of the nucleoid (such a form of bacteriophage is called a prophage). In some cases, the phage genome can behave as a plasmid that replicates independently from the host chromosome (Rybchin and Svarchevsky 1999; Li and Austin 2002). Nevertheless, irrespective of the form of lysogenization, a prophage which is an episome or a plasmid, always requires a living bacterial host to survive. Importantly, under conditions endangering bacterial cell life, a prophage can be induced and the developmental cycle is switched to the lytic one.

The permanent infection, also called the chronic cycle (Pessione 2020), generally resembles the lytic cycle; however, in this case, propagating bacteriophage does not kill its bacterial host (at least not immediately and directly) but progeny virions of the bacteriophage continuously formed are released through a cell envelope without killing the bacterium. Interestingly, this cycle causes a lower growth rate of the host bacterial cell because part of the cell energy is directed to phage functions (Munson-McGee et al. 2018).

\section{The analysis: parasites versus predators}

In the light of various bacteriophage life cycles, let us analyze whether these viruses fulfill the definition of a parasite, a predator, or both. In the beginning, it is worth noting that definitions of parasites and predators and a distinguishment between a parasite and a predator were elaborated primarily based on observations of relationships between multicellular eukaryotic organisms. Therefore, one should consider whether such definitions can reflect any virus-host interactions. For example, in the classical definitions, the way of acquiring nutrients is crucial, while viruses (including bacteriophages) do not need to acquire nutrients the way that, for example, a helminth in an animal gut or a lion hunting for a zebra do. On the other hand, a good biological or ecological definition should reflect all forms of life or biological entities; therefore, it should also be extended to microorganisms and viruses. In fact, although viruses do not acquire nutrients in an animallike manner, and they do not digest food, they still need nucleotides for the synthesis of their nucleic acids, and they still require amino acids to produce their proteins, and those low-molecular-weight compounds must be obtained from their host cells. Hence, definitions of parasites and predators can also be used when considering bacteriophages if remembering the specificity of development and 'nutrition' of these viruses. Considering this, I will discuss bacteriophages as biological entities being either parasites or predators, showing whether they correspond more closely to the former or the latter group of organisms.

The crucial point is that in all kinds of bacteriophage development, all types of bacteriophages require living hosts to propagate. No stage of bacteriophage lytic development can proceed inside a bacterial cell that is dead. The same rule applies to the permanent infection when the living host is necessary to provide resources for continuously developing phages. The living cell is also indispensable for the existence of a prophage; thus, the lysogenic development is fully dependent on the life of the host. Therefore, it appears clear that all bacteriophages meet the conditions of being parasites. They live inside the living host from which they get nutrients and energy for their propagation.

The question remains whether bacteriophages meet the conditions of being predators. Phages kill other organisms (bacteria in this case), as all predators do. However, the vital difference is that bacteriophages cannot use resources of killed organisms to eat them or to propagate. No phage can exploit a dead bacterial cell to perform its biological functions. Therefore, the host's death is an effect of bacteriophage propagation as a parasite rather than a way to obtain nutrients, as in the case of predation. After cell lysis, bacteriophages cannot use any compounds of such a 'prey'; thus, a killed organism is entirely useless for these viruses, indicating a great contrast to typical features of predators that first kill their prey and then eat them.

One more argument for classifying bacteriophages as parasites rather than predators comes from the concept of the general shifts from parasitism to mutualism, demonstrated in various biological systems. Namely, some primary parasites can evolve together with their hosts to form couples of mutualistically cooperating organisms (Paszkowski 2006; Leung and Poulin 2008; Mandyam and Jumpponen 2015; Drew et al. 2021). Importantly, a shift from parasitism to mutualism does not exist when predation is involved, as a predator could never become a symbiont. In this light, it is crucial to indicate that many bacteriophages can provide advantages to their host bacteria, primarily when occurring in the lysogenic state. They include the production of compounds that help the bacterial host to survive in the human or animal gut (Wandro et al. 2019; Dragoš et al. 2021), promotion of 
the fitness of bacterial biofilms (Thingstad et al. 2015), transduction mechanisms allowing DNA exchanges among bacteria (Harrison and Brockhurst 2017), facilitation of bacterial membrane vesicles' formation and release (Turnbull et al. 2016; Toyofuku et al. 2017), and protection of the bacterial population against protist predators (Łoś et al. 2013).

On the other hand, according to Nature Education, "In most situations, parasites do not kill their hosts" (Stevens 2010). Therefore, one might doubt if bacteriophages developing by the lytic cycle can really be called 'parasites'. This dilemma can be solved by introducing the definition of parasitoids - a kind of parasites that exploit their hosts intensively and eventually kill them. The Nature Education indicates that contrary to classical parasites, parasitoids kill their hosts "which blur the line between parasitism and predation", and then, which is crucial: "The major distinguishing difference between parasitoids and predators is that parasitoids feed on living tissue, whereas the predator kills its prey before, or in the process of, consuming it" (Stevens 2010). In this light, prophages (during the lysogenic cycle) and phages developing according to the permanent infection model appear to fulfill the definition of parasites. However, it would be hard to indicate that phages kill their prey before consumption (this is not the case) or even in the process of consumption of bacterial cells, as these viruses use resources of the host for their multiplication rather than 'eat' the bacterium. Therefore, bacteriophages do not meet the requirements indicated in the precise definition of predators and should not be classified as such.

\section{Conclusions}

In summary, all known bacteriophages exploit only living host cells to get nutriment and energy for their propagation which is a characteristic of parasites. On the contrary, although bacteriophages can kill bacterial cells, they cannot use any resources of a dead entity, in contrast to predators that kill the prey and then use them as a source of nutrients. Thus, I conclude that according to biological definitions and ecological relationships between different forms of life, bacteriophages should be classified as parasites rather than predators. This applies especially to phages occurring in host cells as prophages during the lysogenic cycle and those which propagate according to the permanent infection mode. Strictly virulent bacteriophages, which multiply solely by lytic development, can be classified as particular parasites, called parasitoids. They ultimately kill their hosts after exploiting them as sources of chemical compounds and energy required to produce phage progeny.

\section{ORCID}

Grzegorz Węgrzyn https://orcid.org/0000-0003-4042-7466

\section{Acknowledgments}

I thank members of the team I lead for many inspirating discussions. This work was supported by the University of Gdansk (task grant No. 531-D020-D242-21).

\section{Conflict of interest}

The author does not report any financial or personal connections with other persons or organizations, which might negatively affect the contents of this publication and/or claim authorship rights to this publication.

\section{Literature}

Barrios ME, Blanco Fernández MD, Cammarata RV, Torres C, Power P, Mbayed VA. Diversity of beta-lactamase-encoding genes in wastewater: bacteriophages as reporters. Arch Virol. 2021 May; 166(5):1337-1344

https://doi.org/10.1007/s00705-021-05024-y

Batinovic S, Wassef F, Knowler SA, Rice DTF, Stanton CR, Rose J, Tucci J, Nittami T, Vinh A, Drummond GR, et al. Bacteriophages in natural and artificial environments. Pathogens. 2019 Jul 12; 8(3):100. https://doi.org/10.3390/pathogens 8030100

Betts A, Gifford DR, MacLean RC, King KC. Parasite diversity drives rapid host dynamics and evolution of resistance in a bacteriaphage system. Evolution. 2016 May;70(5):969-978.

https://doi.org/10.1111/evo.12909

Bhargava K, Nath G, Bhargava A, Aseri GK, Jain N. Phage therapeutics: from promises to practices and prospectives. Appl Microbiol Biotechnol. 2021 Dec;105(24):9047-9067.

https://doi.org/10.1007/s00253-021-11695-Z

Boyd CM, Angermeyer A, Hays SG, Barth ZK, Patel KM, Seed KD. Bacteriophage ICP1: A persistent predator of Vibrio cholerae. Annu Rev Virol. 2021 Sep 29;8(1):285-304.

https://doi.org/10.1146/annurev-virology-091919-072020

Boyd EF. Bacteriophage-encoded bacterial virulence factors and phage-pathogenicity island interactions. Adv Virus Res. 2012; 82:91-118. https://doi.org/10.1016/B978-0-12-394621-8.00014-5

Casas V, Maloy S. Role of bacteriophage-encoded exotoxins in the evolution of bacterial pathogens. Future Microbiol. 2011 Dec;6(12): 1461-1473. https://doi.org/10.2217/fmb.11.124

Correa AMS, Howard-Varona C, Coy SR, Buchan A, Sullivan MB, Weitz JS. Revisiting the rules of life for viruses of microorganisms. Nat Rev Microbiol. 2021 Aug;19(8):501-513.

https://doi.org/10.1038/s41579-021-00530-x

Dragoš A, Andersen AJC, Lozano-Andrade CN, Kempen PJ, Kovács ÁT, Strube ML. Phages carry interbacterial weapons encoded by biosynthetic gene clusters. Curr Biol. 2021 Aug 23;31(16):34793489.e5. https://doi.org/10.1016/j.cub.2021.05.046

Drew GC, Stevens EJ, King KC. Microbial evolution and transitions along the parasite-mutualist continuum. Nat Rev Microbiol. 2021 Oct;19(10):623-638. https://doi.org/10.1038/s41579-021-00550-7 Duan Y, Young R, Schnabl B. Bacteriophages and their potential for treatment of gastrointestinal diseases. Nat Rev Gastroenterol Hepatol. 2021 Nov 15. https://doi.org/10.1038/s41575-021-00536-Z Fathima B, Archer AC. Bacteriophage therapy: recent developments and applications of a renaissant weapon. Res Microbiol. 2021 SepOct;172(6):103863. https://doi.org/10.1016/j.resmic.2021.103863

Górski A, Międzybrodzki R, Węgrzyn G, Jończyk-Matysiak E, Borysowski J, Weber-Dąbrowska B. Phage therapy: Current status and perspectives. Med Res Rev. 2020 Jan;40(1):459-463.

https://doi.org/10.1002/med.21593 
Gorter FA, Hall AR, Buckling A, Scanlan PD. Parasite host range and the evolution of host resistance. J Evol Biol. 2015 May;28(5): 1119-1130. https://doi.org/10.1111/jeb.12639

Grabowski Ł, Łepek K, Stasiłojć M, Kosznik-Kwaśnicka K, Zdrojewska K, Maciąg-Dorszyńska M, Węgrzyn G, Węgrzyn A. Bacteriophage-encoded enzymes destroying bacterial cell membranes and walls, and their potential use as antimicrobial agents Microbiol Res. 2021 Jul;248:126746.

https://doi.org/10.1016/j.micres.2021.126746

Harada LK, Silva EC, Campos WF, Del Fiol FS, Vila M, Dąbrowska K, Krylov VN, Balcão VM. Biotechnological applications of bacteriophages: State of the art. Microbiol Res. 2018 Jul-Aug;212-213 38-58. https://doi.org/10.1016/j.micres.2018.04.007

Harper DR, Abedon ST, Burrowes BH, McConville ML. Bacteriophages. Biology, technology, therapy. Cham (Switzerland): Springer, Cham; 2021. https://doi.org/10.1007/978-3-319-41986-2

Harrison E, Brockhurst MA. Ecological and evolutionary benefits of temperate phage: What does or doesn't kill you makes you stronger. Bioessays. 2017 Dec;39(12):1700112.

https://doi.org/10.1002/bies.201700112

Hedrich R, Neher E. Venus flytrap: How an excitable, carnivorous plant works. Trends Plant Sci. 2018 Mar;23(3):220-234.

https://doi.org/10.1016/j.tplants.2017.12.004

Hsu CL, Duan Y, Fouts DE, Schnabl B. Intestinal virome and therapeutic potential of bacteriophages in liver disease. J Hepatol. 2021 Dec;75(6):1465-1475. https://doi.org/10.1016/j.jhep.2021.08.003 Iszatt JJ, Larcombe AN, Chan HK, Stick SM, Garratt LW, Kicic A. Phage therapy for multi-drug resistant respiratory tract infections. Viruses. 2021 Sep 11;13(9):1809.

https://doi.org/10.3390/v13091809

Jaroszewicz W, Morcinek-Orłowska J, Pierzynowska K, Gaffke L, Węgrzyn G. Phage display and other peptide display technologies. FEMS Microbiol Rev. 2021 Oct 21:fuab052.

https://doi.org/10.1093/femsre/fuab052

Kortright KE, Chan BK, Koff JL, Turner PE. Phage therapy: A renewed approach to combat antibiotic-resistant bacteria. Cell Host Microbe. 2019 Feb 13;25(2):219-232.

https://doi.org/10.1016/j.chom.2019.01.014

Leung TLF, Poulin R. Parasitism, commensalism, and mutualism: Exploring the many shades of symbioses. Vie et Milieu - Life Environ. 2008;58(2):107-115

Li Y, Austin S. The P1 plasmid in action: time-lapse photomicroscopy reveals some unexpected aspects of plasmid partition. Plasmid. 2002 Nov;48(3):174-178

https://doi.org/10.1016/s0147-619x(02)00104-x

Liu R, Li Z, Han G, Cun S, Yang M, Liu X. Bacteriophage ecology in biological wastewater treatment systems. Appl Microbiol Biotechnol. 2021 Jul;105(13):5299-5307.

https://doi.org/10.1007/s00253-021-11414-8

Łoś JM, Łoś M, Węgrzyn A, Węgrzyn G. Altruism of Shiga toxinproducing Escherichia coli: recent hypothesis versus experimental results. Front Cell Infect Microbiol. 2013 Jan 4;2:166.

https://doi.org/10.3389/fcimb.2012.00166

Łoś JM, Łoś M, Węgrzyn G. Bacteriophages carrying Shiga toxin genes: genomic variations, detection and potential treatment of pathogenic bacteria. Future Microbiol. 2011 Aug;6(8):909-924. https://doi.org/10.2217/fmb.11.70

Łoś M, Czyz A, Sell E, Wegrzyn A, Neubauer P, Wegrzyn G. Bac teriophage contamination: is there a simple method to reduce its deleterious effects in laboratory cultures and biotechnological factories? J Appl Genet. 2004;45(1):111-120.

Łoś M, Węgrzyn G. Pseudolysogeny. Adv Virus Res. 2012;82: 339-349. https://doi.org/10.1016/B978-0-12-394621-8.00019-4 Lourenço M, Chaffringeon L, Lamy-Besnier Q, Pédron T, Campagne P, Eberl C, Bérard M, Stecher B, Debarbieux L, De Sordi L.
The spatial heterogeneity of the gut limits predation and fosters coexistence of bacteria and bacteriophages. Cell Host Microbe. 2020 Sep 9;28(3):390-401.e5

https://doi.org/10.1016/j.chom.2020.06.002

Mandyam KG, Jumpponen A. Mutualism-parasitism paradigm synthesized from results of root-endophyte models. Front Microbiol. 2015 Jan 12;5:776. https://doi.org/10.3389/fmicb.2014.00776 Mgomi FC, Yuan L, Chen CW, Zhang YS, Yang ZQ. Bacteriophages: A weapon against mixed-species biofilms in the food processing environment. J Appl Microbiol. 2021 Dec 21;00:1-15. https://doi.org/10.1111/jam.15421

Munson-McGee JH, Snyder JC, Young MJ. Archaeal viruses from high-temperature environments. Genes (Basel). 2018 Feb 27;9(3):128. https://doi.org/10.3390/genes9030128

Naureen Z, Dautaj A, Anpilogov K, Camilleri G, Dhuli K, Tanzi B, Maltese PE, Cristofoli F, De Antoni L, Beccari T, et al. Bacteriophages presence in nature and their role in the natural selection of bacterial populations. Acta Biomed. 2020 Nov 9;91(13-S):e2020024. https://doi.org/10.23750/abm.v91i13-S.10819

Noureen S, Noreen S, Ghumman SA, Batool F, Bukhari SNA. The genus Cuscuta (Convolvolaceae): An updated review on indigenous uses, phytochemistry, and pharmacology. Iran J Basic Med Sci. 2019 Nov;22(11):1225-1252.

https://doi.org/10.22038/ijbms.2019.35296.8407

Orzechowska B, Mohammed M. The war between bacteria and bacteriophages. In: Mishra M, editor. Growing and handling of bacterial cultures. London (UK): IntechOpen; 2019.

https://doi.org/10.5772/intechopen.87247

Paszkowski U. Mutualism and parasitism: the yin and yang of plant symbioses. Curr Opin Plant Biol. 2006 Aug;9(4):364-370.

https://doi.org/10.1016/j.pbi.2006.05.008

Pessione E. The Russian doll model: How bacteria shape successful and sustainable inter-kingdom relationships. Front Microbiol 2020 Oct 20;11:573759. https://doi.org/10.3389/fmicb.2020.573759

Podlacha M, Grabowski Ł, Kosznik-Kawśnicka K, Zdrojewska K, Stasiłojć M, Węgrzyn G, Węgrzyn A. Interactions of bacteriophages with animal and human organisms-safety issues in the light of phage therapy. Int J Mol Sci. 2021 Aug 19;22(16):8937.

https://doi.org/10.3390/ijms22168937

Rybchin VN, Svarchevsky AN. The plasmid prophage N15: a linear DNA with covalently closed ends. Mol Microbiol. 1999 Sep;33(5): 895-903. https://doi.org/10.1046/j.1365-2958.1999.01533.x

Salmond GP, Fineran PC. A century of the phage: past, present and future. Nat Rev Microbiol. 2015 Dec;13(12):777-786.

https://doi.org/10.1038/nrmicro3564

Srinivasiah S, Bhavsar J, Thapar K, Liles M, Schoenfeld T, Wommack KE. Phages across the biosphere: contrasts of viruses in soil and aquatic environments. Res Microbiol. 2008 Jun;159(5):349-357. https://doi.org/10.1016/j.resmic.2008.04.010

Stevens A. Predation, herbivory, and parasitism [Internet]. Nature Education Knowledge. 2010;3(10):36 [cited 2021 Nov 10].

Available from https://www.nature.com/scitable/knowledge/library/ predation-herbivory-and-parasitism-13261134/

Tetz G, Tetz V. Bacteriophages as new human viral pathogens. Microorganisms. 2018 Jun 16;6(2):54.

https://doi.org/10.3390/microorganisms6020054

Tetz GV, Ruggles KV, Zhou H, Heguy A, Tsirigos A, Tetz V. Bacteriophages as potential new mammalian pathogens. Sci Rep. 2017 Aug 1;7(1):7043. https://doi.org/10.1038/s41598-017-07278-6 Thingstad TF, Pree B, Giske J, Våge S. What difference does it make if viruses are strain-, rather than species-specific? Front Microbiol. 2015 Apr 20;6:320. https://doi.org/10.3389/fmicb.2015.00320

Tian F, Li J, Nazir A, Tong Y. Bacteriophage - A promising alternative measure for bacterial biofilm control. Infect Drug Resist. 2021 Jan 20;14:205-217. https://doi.org/10.2147/IDR.S290093 
Topka-Bielecka G, Dydecka A, Necel A, Bloch S, NejmanFaleńczyk B, Węgrzyn G, Węgrzyn A. Bacteriophage-derived depolymerases against bacterial biofilm. Antibiotics (Basel). 2021 Feb 10;10(2):175.

https://doi.org/10.3390/antibiotics10020175

Toyofuku M, Cárcamo-Oyarce G, Yamamoto T, Eisenstein F, Hsiao C-C, Kurosawa M, Gademann K, Pilhofer M, Nomura N, Eberl L. Prophage-triggered membrane vesicle formation through peptidoglycan damage in Bacillus subtilis. Nat Commun. 2017 Sep 7;8(1):481. https://doi.org/10.1038/s41467-017-00492-w

Turnau K, Fiałkowska E, Ważny R, Rozpądek P, Tylko G, Bloch S, Nejman-Faleńczyk B, Grabski M, Węgrzyn A, Węgrzyn G. Extraordinary multi-organismal interactions involving bacteriophages, bacteria, fungi, and rotifers: Quadruple microbial trophic network in water droplets. Int J Mol Sci. 2021 Feb 22;22(4):2178.

https://doi.org/10.3390/ijms22042178
Turnbull L, Toyofuku M, Hynen AL, Kurosawa M, Pessi G, Petty NK, Osvath SR, Cárcamo-Oyarce G, Gloag ES, Shimoni R, et al. Explosive cell lysis as a mechanism for the biogenesis of bacterial membrane vesicles and biofilms. Nat Commun. 2016 Apr 14;7: 11220. https://doi.org/10.1038/ncomms11220

Wandro S, Oliver A, Gallagher T, Weihe C, England W, Martiny JBH, Whiteson K. Predictable molecular adaptation of coevolving Enterococcus faecium and lytic phage EfV12-phi1. Front Microbiol. 2019 Jan 31;9:3192. https://doi.org/10.3389/fmicb.2018.03192 Zalewska-Piątek B, Piątek R. Bacteriophages as potential tools for use in antimicrobial therapy and vaccine development. Pharmaceuticals (Basel). 2021 Apr 5;14(4):331. https://doi.org/10.3390/ph14040331

Zhang Y, Li CX, Zhang XZ. Bacteriophage-mediated modulation of microbiota for diseases treatment. Adv Drug Deliv Rev. 2021 Sep; 176:113856. https://doi.org/10.1016/j.addr.2021.113856 